\title{
A educação é realmente imprescindível para o desenvolvimento?
}

\author{
Is education really indispensable for development?
}

Em época eleitoral e mesmo fora dela, os candidatos e os detentores do poder político porfiam em promessas e planos subordinados ao lema "educação e saúde". É com insistência, e porque não dizê-lo, bastante irritativo, que o atual governo transmita pelo rádio propaganda inusitada e de gosto bastante discutível, atrelada ao que seria, "educação, dever do Estado". Ora bem, diante disso, caberia perguntar se, afinal, a educação vai inelutavelmente ao encontro do processo de desenvolvimento em nação moderna e industrializada. É bem verdade que subsistem certas dúvidas de se o nosso país poderia ser enquadrado, como um todo, no rol das nações modernas e industrializadas. De qualquer maneira, no estado atual de nossa sociedade, é de se pensar não ser de todo descabido meditar sobre 0 assunto.

À primeira vista, a resposta àquela pergunta parece óbvia. De modo otimista admite-se que, apesar de tudo, as coisas têm melhorado com o passar do tempo e constitui consenso o atribuir à educação boa parcela de responsabilidade nisso. $E$ assim, o grau de alfabetização tem-se constituído em parâmetro para avaliar o nível de desenvolvimento cultural atingido pela população. A pobreza e a prevalência de muitas doenças teriam, na ignorância e no iletrismo, as condições propícias para medrarem. Em decorrência, a educação seria o remédio essencial para romper essa situação e possibilitar o progresso econômico e social. No entanto, a assim denominada sociedade pós-industrial tem dado lugar a mudanças que tendem a motivar o repensamento desses conceitos, tidos até agora como inquestionáveis (Rose, 1994).

Em primeiro lugar, o crescer avassalador da tecnologia tende ao estabelecimento de novos papéis e funções a serem desempenhados. Isso implica transformação da força de trabalho, no sentido de se tornar mais reduzida e mais especializada. Conseqüentemente, os novos empregos passam a ter, no aprendizado e no treinamento, feição de continuidade que os caracteriza, com freqüentes reciclagens. Em segundo lugar, e como decorrência, os cursos de formação deixam, cada vez mais, de desenvolver adequadamentéas habilidades necessárias para a ocupação desses novos empregos tecnológicos. Com isso, grande parte da possível força de trabalho torna-se progressivamente desabilitada. E assim, nas sociedades ditas modernas, tornam-se progressivamente menos estreitos os liames entre o trabalho e a intelectualização, para não dizer a instrução primária.

Todavia, mesmo no âmbito dessa situação essencialmente tecnológica deverá haver lugar para a tomada de decisões e para o pensamento crítico, sem os quais dificilmente a pura e simples habilidade técnica dificilmente terá a eficácia desejada. No momento atual, as sociedades assim chamadas de desenvolvidas reservam a si esse papel, enquanto cada vez mais recrutam, nas populações das sociedades assim ditas em desenvolvimento, os elementos passíveis de aprenderem as técnicas de que necessitam. Como resultado, e de maneira não desprezível, atingem o objetivo de abrir novos mercados para o consumo. Assim pois, quais as perspectivas para os países do terceiro mundo? O que fazer, uma vez que o seu desenvolvimento econômico está atrelado à tecnologia, do primeiro mundo? A resposta óbvia seria a de que desenvolvessem a própria tecnologia, mas isso, na maioria dos setores, não passa de intenção utópica. Por esse motivo, quem sabe o investimento em pesquisa básica, pelo menos para seus problemas mais prementes, poderá se traduzir em futuro próximo, em tecnologia autóctone. Até lá, não há como deixar de admitir que a nossa educação deverá ser ainda a fundamental e generalista. Para adquirir a especializada, enviamos nossa juventude aos países assim ditos adiantados, de onde voltam para repetir o que aprenderam. 
Contudo, mesmo nas nações que se encontram na liderança tecnológica, o quadro atual poderá mudar em breve tempo. E de maneira pior para o terceiro mundo. Eis que, há menos de dez anos lançou-se o projeto denominado de "vida artificial" ("artificial life") que consiste, nada mais nada menos, em criar seres bioquimicamente constituídos à base de silício. Como disso se pode depreender, trata-se do âmbito do computador, o qual, como ecossistema, abrigaria populações artificiais capazes de evoluírem, de se reproduzirem e de competirem em (Levy, 1992). O passo seguinte será o dos autômatos, mais conhecidos como "robots", que substituirão os seres humanos nas atividades especializadas. Caberá pois pergunta final. E se esses seres adquirirem consciência?

\section{Oswaldo Paulo Forattini}

Editor

\section{Referências Bibliográficas}

ROSE, A. Defining the role of education in economic development. Adult Learning, 5(5):5, 1994.

LEVY, S. Artificial life. The quest for a new creative. London, Penguin Books Ltda, 1992. 